\title{
Novel mechanisms of growth hormone regulation: growth hormone-releasing peptides and ghrelin
}

A.-M.J. Lengyel

\section{Correspondence}

A.-M.J. Lengyel

Divisão de Endocrinologia

EPM, UNIFESP

R. Pedro de Toledo, 910

04039-002 São Paulo, SP

Brasil

Fax: +55-11-5574-8432

E-mail: amlengyel@rocketmail.com

Research supported by FAPESP (Nos. 97/07689-0, 02/03508-0, and 02/14118-9) and CNPq (No. 300550/87-1). A.-M.J. Lengyel is a Senior Scientist of CNPq.

Received July 20, 2005 Accepted May 29, 2006
Divisão de Endocrinologia, Escola Paulista de Medicina, Universidade Federal de São Paulo, São Paulo, SP, Brasil

\begin{abstract}
Growth hormone secretion is classically modulated by two hypothalamic hormones, growth hormone-releasing hormone and somatostatin. A third pathway was proposed in the last decade, which involves the growth hormone secretagogues. Ghrelin is a novel acylated peptide which is produced mainly by the stomach. It is also synthesized in the hypothalamus and is present in several other tissues. This endogenous growth hormone secretagogue was discovered by reverse pharmacology when a group of synthetic growth hormone-releasing compounds was initially produced, leading to the isolation of an orphan receptor and, finally, to its endogenous ligand. Ghrelin binds to an active receptor to increase growth hormone release and food intake. It is still not known how hypothalamic and circulating ghrelin is involved in the control of growth hormone release. Endogenous ghrelin might act to amplify the basic pattern of growth hormone secretion, optimizing somatotroph responsiveness to growth hormone-releasing hormone. It may activate multiple interdependent intracellular pathways at the somatotroph, involving protein kinase $\mathrm{C}$, protein kinase $\mathrm{A}$ and extracellular calcium systems. However, since ghrelin has a greater ability to release growth hormone in vivo, its main site of action is the hypothalamus. In the current review we summarize the available data on the: a) discovery of this peptide, b) mechanisms of action of growth hormone secretagogues and ghrelin and possible physiological role on growth hormone modulation, and c) regulation of growth hormone release in man after intravenous administration of these peptides.
\end{abstract}

\section{Introduction}

In 1982, before the identification of growth hormone-releasing hormone (GHRH), Bowers et al. (1) discovered a new group of synthetic substances with growth hormone (GH)-releasing ability (for a review, see Ref. 2). These compounds were developed from
Key words

- Growth hormone

- Growth hormone

secretagogues

- Ghrelin

- Somatostatin

- Hypothalamus the met-enkephalin molecule by theoretical conformational energy calculations, computer modelling, peptide chemical modifications, and studies of biological activity. Initially these small peptides were able to release GH weakly. Further chemical modifications led to the development of more potent compounds, including peptides such as 
GH-releasing peptide-6 (GHRP-6), GHRP2, hexarelin, and non-peptides such as MK0677, which could be administered orally (2). In the last decade several studies were performed with these growth hormone secretagogues (GHS), especially with GHRP6 , and the results suggested a possible role for these peptides in $\mathrm{GH}$ modulation (3). It was demonstrated that GHS release GH by different mechanisms than those stimulated by GHRH (for reviews, see Refs. 2,3). Furthermore, these peptides act through different receptors than those of GHRH, somatostatin or opioid peptides. In 1996, Howard et al. (4) cloned the GHS receptor (GHS-R), which was mainly located in the anterior pituitary and in the brain, both in hypothalamic and non-hypothalamic areas. In 1999, Kojima et al. (5) discovered the endogenous ligand for these orphan receptors in the stomach, and this new hormone was designated ghrelin (from ghre, the Indo-European root of the word "grow"). Ghrelin is also present in small amounts in the hypothalamus and induces $\mathrm{GH}$ release in a quite potent manner $(5,6)$. This peptide is a new member of the brain-gut peptide family, and is also involved in the control of appetite, an effect apparently independent of GH release (for reviews, see Refs. 7,8). Ghrelin might have other actions, which are currently being investigated $(7,8)$. The discovery of ghrelin is an excellent example of reverse pharmacology, in which a new hormone was isolated starting from the chemical synthesis of compounds such as GHS, which then led to the discovery of the endogenous orphan receptor and finally to the isolation of its natural ligand.

\section{Growth hormone secretagogue receptor}

In 1996 Howard et al. (4) cloned the GHS-R, which belongs to the G-protein family. It has seven transmembrane-spanning segments and three intracellular and extra- cellular loops. There are two subtypes of receptors, GHS-R1a, which is active, and GHS-R1b, a shorter isoform, which apparently does not have biological activity (4). Other subtypes might also exist. The human GHS-R1a has 366 amino acids and is highly conserved in evolution. It is located in the anterior pituitary and in the hypothalamus, and in other areas of the brain, such as hippocampus and substantia nigra (4). GHS$\mathrm{R} 1 \mathrm{a}$ was found in several areas of the hypothalamus, including the arcuate, ventromedial and paraventricular nuclei $(2,4)$. Because of its location it has been suggested that GHS-R might modulate biological rhythms, mood, memory, learning, and appetite (2). In the pituitary GHS-R was detected exclusively in somatotrophs by immunocytochemistry (2). In knockout mice for GHS-R1a ghrelin is unable to increase $\mathrm{GH}$ release or food intake, which indicates that this type of receptor is involved in both actions of ghrelin (9). It was also shown that GHS-R1a is present in other tissues such as pancreas, heart, adrenal gland, and the thyroid (10). It is interesting that GHS-R1b has a widespread distribution in peripheral tissues but its function is still unknown (10). As mentioned previously, it is likely that other receptor subtypes might also exist.

\section{Ghrelin: overview}

When different tissue extracts were added to an experimental system with cells expressing human GHS-R1a, Kojima et al. (5) surprisingly found a major increase in intracellular calcium concentrations with the addition of stomach extracts. These investigators isolated a 28 -amino acid peptide with a fatty acid chain modification (n-octanoic acid), in the serine 3 residue. This hydrophobic compound, which is the first known natural bioactive peptide modified by an acyl acid, was called ghrelin. An intriguing finding was the lack of structural similarity between ghrelin and the GHS, such as GHRP- 
6 (5). The post-translational fatty acid chain modification (n-octanoyl residue) is essential for some of its biological activity, including GH release and appetite stimulation. Shorter fragments, with the first four to five residues, but with intact acylated serine, are also able to activate signal transduction of GHS-R1a in vitro (7). Non-acylated ghrelin, which is the main circulating form, might have non-endocrine actions (5). This latter peptide is mainly secreted from the stomach as its circulating levels are reduced by $80 \%$ after gastrectomy or gastric bypass in humans (11). It was recently shown that ghrelin crosses the blood brain barrier, and this transport occurs in both directions, from blood to brain and from the central nervous system to blood (12). It has also been shown that the acyl residue is important for this transport (12). The gene that encodes ghrelin was also identified (5) and is located on chromosome 3 in man. This gene encodes a precursor of 117 amino acids, with an $82 \%$ homology within species (5). In the stomach, two isoforms of prepro-ghrelin mRNA are produced by the same gene by alternative splicing (5). One encodes the ghrelin precursor while the other encodes des-Gln ${ }^{14}$ ghrelin precursor, which lacks glutamine at position 14 (5). This latter peptide has 27 amino acids and is biologically active, but is present in small amounts. Therefore, the main active form is ghrelin. Ghrelin is located in the submucosal layer of the stomach fundus, in endocrine oxyntic cells (X/A) which are near the capillaries and not in contact with the lumen, and also, at lower concentrations, in the gastrointestinal tract (7). Both ghrelin and its mRNA are present in the arcuate nucleus of the hypothalamus and in the pituitary gland $(5,10)$. Both n-octanoyl-modified, which is the major form, and des-acyl ghrelin were recently identified in the rat hypothalamus. At the pituitary level ghrelin might act in autocrine or paracrine manner. Recently, it has been shown that ghrelin is expressed in lactotrophs, somatotrophs and thyrotrophs, cells which are dependent on Pit-1 gene expression for differentiation (8). Interestingly, ghrelin is capable of modulating Pit-1 transcription. In peripheral tissues ghrelin has a widespread distribution and has been found in the kidney, placenta, lung, ovary, and testis, among others, but its physiological role in these locations remains to be elucidated (10). Since the distribution of the biologically active receptor (GHS-R1a) is not the same as the peptide, it is likely that other receptor subtypes might exist (10). Considerable amounts of ghrelin are present in blood and this peptide has several actions apart from GH regulation $(7,8)$. Ghrelin enhances food consumption by activation of NPY/AGRP (agouti-related protein) neurons in the hypothalamus, while leptin has the opposite effect $(7,8)$. Ghrelin is able to increase GH release both in animals and in man, and also induces prolactin, ACTH, cortisol, and aldosterone secretion in vivo $(5,6,13,14)$. Ghrelin causes a slight increase in glucose levels and a reduction of circulating insulin (14). The discovery of ghrelin reinforced the concept of a third pathway of $\mathrm{GH}$ regulation $(2,3,7,8)$. However, the physiological role of this potent endogenous GHRP remains to be determined.

\section{Mechanism of action and physiological role of GHS and ghrelin on $\mathrm{GH}$ release}

GHS and ghrelin act at both hypothalamic and pituitary levels to modulate GH secretion (for reviews, see Refs. 3,7,8). These peptides directly activate the GHS-R in pituitary cells in vitro to stimulate GH release (5). When GHRH is associated with GHS or ghrelin in vitro, an additive response is observed in most studies. However, when these peptides are administered together with GHRH in vivo, a synergistic effect on GH release is observed, which indicates different mechanisms of action of GHS and GHRH and suggests a main hypothalamic site of 
action of GHS (6,14-16). Moreover, in hypothalamic pituitary disconnection there is a lack of GH release after GHRP-6 or ghrelin, both in animals and in man $(17,18)$. It has been shown that an intact GHRH system is necessary for these actions to occur. The administration of antibodies against GHRH decreases both GH pulsatility and GH responsiveness to ghrelin and GHS in rats (19). GHS-induced GH release is also inhibited by a GHRH antagonist (20). In the lit/lit mouse, which has a GHRH receptor mutation, GHS do not increase GH release, but there is an enhancement of hypothalamic $c$ fos expression, which is a marker of neuronal activity (21). The GH response to GHS is blunted in humans with GHRH receptor mutations, but the ACTH- and prolactinreleasing effects are preserved, suggesting that they are mediated by the hypothalamus (22). The arcuate nucleus is the main target of ghrelin action, where ghrelin may bind and activate the GHS-R. It has been shown

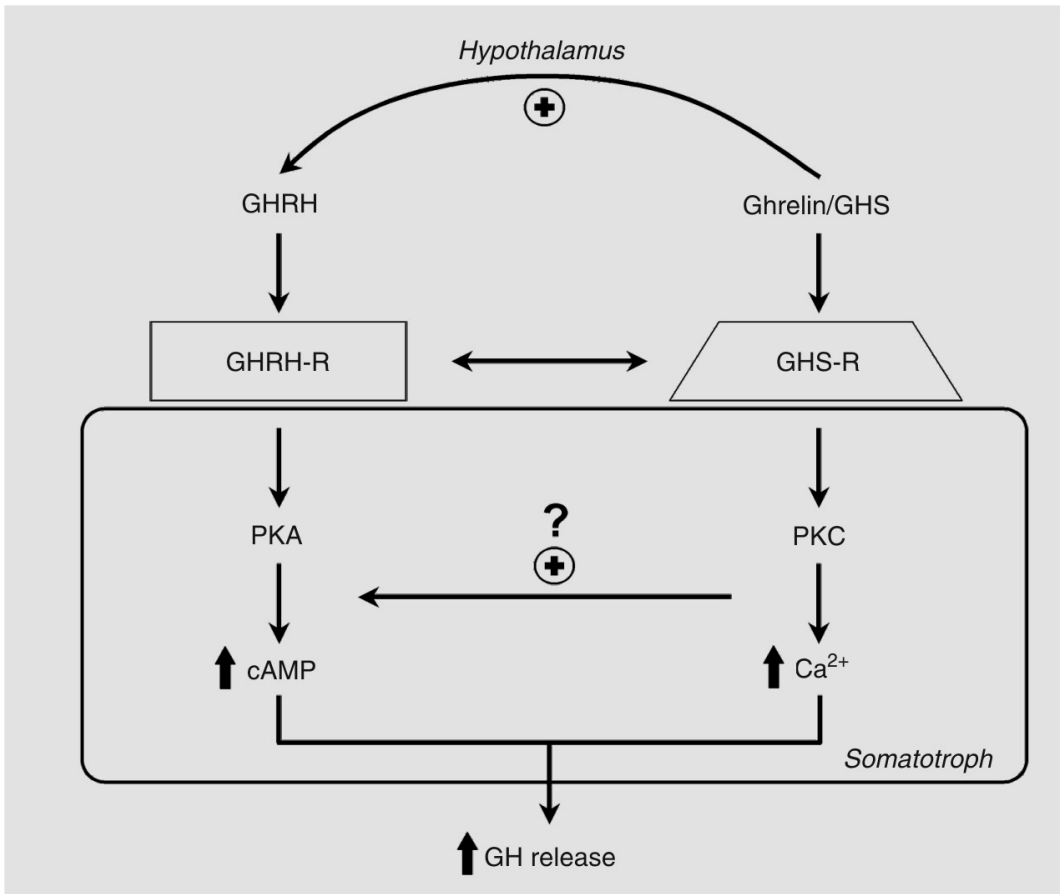

Figure 1. Proposed model of the interactions between GHRH and ghrelin/GHS at the hypothalamic and pituitary level. GHRH = growth hormone-releasing hormone; GHS = growth hormone secretagogues; PKA = protein kinase $\mathrm{A} ; \mathrm{PKC}=$ protein kinase $\mathrm{C}$. Taken in part from ref. 20, with permission. that GHS and ghrelin act centrally by increasing electrical activity and $c$-fos expression in a subpopulation of cells in the arcuate nucleus, some of which are GHRH-producing neurons (21). Moreover, one fourth of these GHRH neurons express the GHS-R, suggesting a direct effect of GHS on these cells (19) (Figure 1).

Ghrelin also increases GHRH release from hypothalamic tissue in vitro, but this was not observed with GHS $(23,24)$. It has also been shown that GHS increase GHRH release into the pituitary portal system in sheep (25). GHS and ghrelin did not alter hypothalamic somatostatin release in most in vivo and in vitro studies (23-25). However, GHS act as functional somatostatin antagonists $(19,26)$. GHS cause depolarization of the somatotroph and an increase in the number of cells secreting GH, while somatostatin has the opposite effect (26).

A model for the action of GHS/ghrelin has been proposed which involves: 1) a functional antagonism of somatostatin; 2) activation of GHRH producing neurons in the arcuate nucleus, leading to an increase in GHRH release; 3) amplification of the effect of GHRH at the somatotroph level (2). At the pituitary level, GHS/ghrelin and GHRH bind to different receptors, and there is evidence of cross-talk between them (for a review, see Ref. 7). These peptides also activate different intracellular transduction pathways at the somatotroph level. GHRH stimulates intracellular cyclic AMP and protein kinase A mechanisms, while GHRP-6 activates protein kinase $\mathrm{C}$, via inositol triphosphate signal transduction, with an increase in intracellular calcium concentrations $(2,4)$ (Figure 1). Interestingly, it has been recently shown in pigs that ghrelin is able to stimulate multiple, interdependent, intracellular pathways at the somatotroph level, involving protein kinase $\mathrm{A}, \mathrm{C}$ and extracellular calcium systems, with a broader effect than that of most GHS, but similar to that reported for GHRP-2 in this species (27). These data also 
suggest the possibility of cross-talk between these transduction pathways. However, the physiological role of these potent stimulators of GH release is not clear.

A controversial issue is whether circulating ghrelin has a role in pituitary GH secretion. It is also unknown how the hypothalamic peptide participates in GH modulation. In the rat, ghrelin secretion occurs in a pulsatile manner, with no correlation with GH pulses, but in association with feeding and sleeping cycles (28). Also, circulating ghrelin levels were similar during the $\mathrm{GH}$ peak and trough periods in the rat (29). Ghrelin immunoneutralization did not alter GH pulsatility, while GHRH antibodies completely blocked endogenous pulsatile $\mathrm{GH}$ release (30). In humans, the administration of a GHRH antagonist strongly inhibited 24$\mathrm{h}$ GH secretion, but failed to affect circulating ghrelin levels (31). However, in rats, intracerebroventricular or peripheral administration of GHS-R1a antagonists attenuated spontaneous GH secretion, basically by a decrease in pulse amplitude and mean GH levels (32-34). Interestingly, a missense mutation in the GHS-R, which severely impaired ghrelin binding, was associated with a case of familial short stature (35). It has also been shown in healthy volunteers that circulating ghrelin is related to GH pulses, suggesting that ghrelin participates in the pulsatile regulation of GH secretion or that the two hormones are regulated in parallel (36). Therefore, endogenous ghrelin might amplify the basic pattern of GH secretion (32-34). This peptide may also have a physiological role in $\mathrm{GH}$ release by optimizing somatotroph responsiveness to GHRH (37). Nevertheless, recent studies with ghrelin knockout animals failed to show a major effect on GH regulation (38). In contrast to predictions, these animals were not anorexic dwarfs (38). However, reduced GH and IGFI levels were observed in transgenic models with decreased GHS-R mRNA expression in the arcuate nucleus (39). Also, GHS-R knockout mice had lower body weight and IGF-I values (40). These effects were only moderate, which is intriguing, since these peptides are quite potent $\mathrm{GH}$ stimulators. It has been suggested that the role of ghrelin in GH secretion might become more relevant during states of negative energy balance (30). However, further studies are necessary to elucidate the physiological role of these peptides in $\mathrm{GH}$ secretion.

\section{Regulation of GH secretion by GHRP-6 and ghrelin in man}

GHRP-6 and ghrelin increase GH release in a dose-dependent manner both in vivo and in vitro in several species, including man $(1,5,6,13,16)$. The GH-releasing activity of ghrelin is similar to that of GHRH in vitro (5). However, in man, iv ghrelin administration at a dose of $1 \mu \mathrm{g} / \mathrm{kg}$ increases $\mathrm{GH}$ release in a potent manner and this response is higher than that obtained with GHRH, hexarelin and GHRP-6 $(13,14,41)$. This effect is not specific since there is also an increase in prolactin, ACTH, cortisol, and aldosterone (14). Insulin values decrease and glucose levels increase after $i v$ administration of this peptide (14). The latter effects and the aldosterone stimulation are not seen with other GHS. When ghrelin or GHRP-6 is administered together with GHRH a synergistic effect is seen, but with ghrelin this is better observed with low doses of this peptide $(0.08$ and $0.2 \mu \mathrm{g} / \mathrm{kg})(14,16)$. It has been demon-

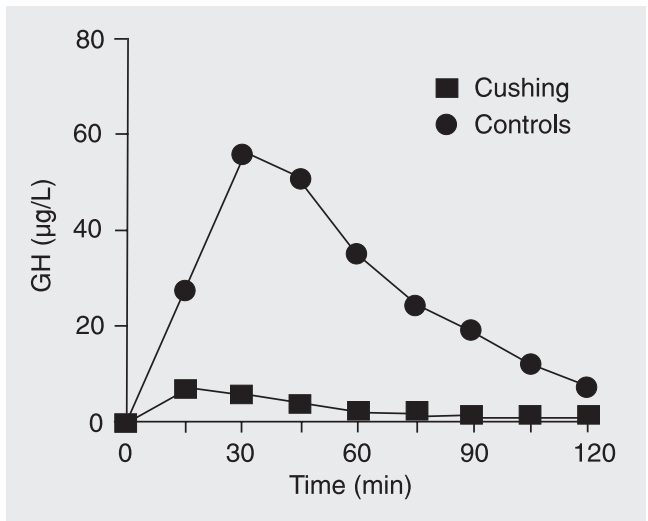

Figure 2. Serum growth hormone $(\mathrm{GH})$ concentration after ghrelin administration $(1 \mu \mathrm{g} / \mathrm{kg}$, iv) in patients with Cushing's disease $(\mathrm{N}=12)$ and in controls $(\mathrm{N}=9)$ (from Ref. 58, with permission). 
strated that the combined administration of GHRP-6 and GHRH is an excellent test for the diagnosis of GH deficiency in adults. There are no gender differences in the $\mathrm{GH}$ responsiveness to GHRP-6 and ghrelin (3, 15,42 ), but an age-related decrease of the response has been reported for both peptides $(3,15,42)$. Obese subjects have blunted GH responses to GHRP-6 and ghrelin $(43,44)$. Recently, a 55\% decrease in ghrelin-induced GH release was shown in women with visceral adiposity and a body mass index of $36.2 \mathrm{~kg} / \mathrm{m}^{2}(44)$. There is a highly reproducible response to GHS in normal subjects studied on different occasions, different from that observed for GHRH. Hyperglycemia, free fatty acids and somatostatin decrease GHRP-6 and the ghrelin-induced GH response $(45,46)$. Arginine was not able to alter $\mathrm{GH}$ responsiveness to ghrelin (47).

The effect of cholinergic agonists and antagonists on ghrelin-induced GH release is controversial. Pyridostigmine failed to modify GH responsiveness to both ghrelin and GHRP-6 (15,48). However, atropine blunted this response, but pirenzepine, a muscarinic receptor antagonist, was not able to alter GH release after ghrelin (48). These latter compounds only blunt the $\mathrm{GH}$ response to GHRP-6, while they completely abolish the GH response to GHRH (15). Glucocorticoid and GH administration, which probably enhances hypothalamic somatostatin release, only attenuates the $\mathrm{GH}$ response to GHS (49,50).

In patients with Cushing's disease, a blunted GH response to both GHRP-6 and ghrelin has been reported by us and by others (51-54) (Figure 2). In these patients GHSand ghrelin-induced ACTH and cortisol release is enhanced (53-55), which could be due to a direct action of these peptides on the GHS-R in the corticotroph adenoma or, perhaps, activation of hypothalamic arginine vasopressin and also, to some extent, corticotrophin-releasing hormone pathways (7). Interestingly, chronic glucocorticoid admin- istration does not interfere with GHRP-6induced GH release (52). This might indicate, as suggested previously, that the time of exposure to hypercortisolism determines the GH response to these peptides. In adrenal insufficiency a 72-h withdrawal of glucocorticoid replacement therapy does not influence the GH responsiveness to GHRP6 (56). In hyperthyroidism we have observed a decrease in $\mathrm{GH}$ responsiveness to GHRH while GHRP-6-induced GH release was maintained, which could suggest that thyroid hormones interfere with GHRH-releasing mechanisms, with preservation of GHRP6-activated pathways (57). Interestingly, we have recently shown that there is a decrease in the GH response to ghrelin in these patients, suggesting that thyroid hormones interfere with additional pathways of $\mathrm{GH}$ release activated by ghrelin (58). In type 1 diabetes mellitus the GH response to GHRP6 and hexarelin is either normal or enhanced, demonstrating that hyperglycemia is unable to decrease the GH release induced by these peptides, differently than in normal subjects (59). It has recently been shown that ghrelininduced GH release is decreased in anorexia nervosa, which is an unexpected finding because these patients have high GH levels and enhanced responses to GHRH and GHS (60). The possibility that GH-releasing substances, especially the orally active compounds, could represent an alternative treatment in GH-deficient states has received considerable attention. However, these substances have failed to show benefit over GH therapy, although they would be considered more physiological since they induce endogenous pulsatile $\mathrm{GH}$ release.

\section{Conclusion}

Ghrelin is a new hormone secreted from the stomach to the circulation, but is also produced in the hypothalamus and other tissues, with both endocrine and paracrine effects. Its acyl modification is essential for its 
biological effects of enhancement of GH release and stimulation of food intake. Several questions remain to be answered concerning the roles of circulating and hypothalamic ghrelin in GH secretion. The available data suggest that ghrelin might have a physiological role in pulsatile GH release, but further studies are necessary to clarify its precise role in $\mathrm{GH}$ modulation.

\section{Acknowledgments}

The author thanks the following colleagues from Escola Paulista de Medicina: the postgraduate students who contributed to this study, Prof. Dr. José G.H. Vieira for constant laboratory support, and Aparecida Filomena Machado and Walkiria Miranda for assistance with the assays.

\section{References}

1. Bowers CY, Momany FA, Reynolds GA, Hong A. On the in vitro and in vivo activity of a new synthetic hexapeptide that acts on the pituitary to specifically release growth hormone. Endocrinology 1984; 114: 1537-1545.

2. Smith RG, Van der Ploeg LH, Howard AD, Feighner SD, Cheng K, Hickey GJ, et al. Peptidomimetic regulation of growth hormone secretion. Endocr Rev 1997; 18: 621-645.

3. Korbonits M, Grossman A. Growth hormone-releasing peptide and its analogues-novel stimuli to growth hormone release. Trends Endocrinol Metab 1995; 6: 43-49.

4. Howard AD, Feighner SD, Cully DF, Arena JP, Liberator PA, Rosenblum $\mathrm{Cl}$, et al. A receptor in pituitary and hypothalamus that functions in growth hormone release. Science 1996; 273: 974-977.

5. Kojima M, Hosoda H, Date $Y$, Nakazato M, Matsuo H, Kangawa K. Ghrelin is a growth-hormone-releasing acylated peptide from stomach. Nature 1999; 402: 656-660.

6. Arvat E, DiVito L, Broglio F, Papotti M, Muccioli G, Dieguez C, et al. Preliminary evidence that ghrelin, the natural $\mathrm{GH}$ secretagogue (GHS)-receptor ligand, strongly stimulates $\mathrm{GH}$ secretion in humans. $J$ Endocrinol Invest 2000; 23: 493-495.

7. Korbonits M, Goldstone AP, Gueorguiev M, Grossman AB. Ghrelin a hormone with multiple functions. Front Neuroendocrinol 2004; 25: 27-68.

8. van der Lely AJ, Tschop M, Heiman ML, Ghigo E. Biological, physiological, pathophysiological, and pharmacological aspects of ghrelin. Endocr Rev 2004; 25: 426-457.

9. Sun $Y$, Wang $P$, Zheng $H$, Smith RG. Ghrelin stimulation of growth hormone release and appetite is mediated through the growth hormone secretagogue receptor. Proc Natl Acad Sci U S A 2004; 101 : 4679-4684.

10. Gnanapavan S, Kola B, Bustin SA, Morris DG, McGee P, Fairclough $P$, et al. The tissue distribution of the mRNA of ghrelin and subtypes of its receptor, GHS-R, in humans. J Clin Endocrinol Metab 2002; 87: 2988.

11. Cummings DE, Weigle DS, Frayo RS, Breen PA, Ma MK, Dellinger $E P$, et al. Plasma ghrelin levels after diet-induced weight loss or gastric bypass surgery. N Engl J Med 2002; 346: 1623-1630.

12. Banks WA, Tschop M, Robinson SM, Heiman ML. Extent and direction of ghrelin transport across the blood-brain barrier is determined by its unique primary structure. J Pharmacol Exp Ther 2002; 302: 822-827.

13. Takaya K, Ariyasu H, Kanamoto N, Iwakura H, Yoshimoto A, Harada
M, et al. Ghrelin strongly stimulates growth hormone release in humans. J Clin Endocrinol Metab 2000; 85: 4908-4911.

14. Arvat E, Maccario M, Di Vito L, Broglio F, Benso A, Gottero C, et al. Endocrine activities of ghrelin, a natural growth hormone secretagogue (GHS), in humans: comparison and interactions with hexarelin, a nonnatural peptidyl GHS, and GH-releasing hormone. J Clin Endocrinol Metab 2001; 86: 1169-1174.

15. Penalva A, Carballo A, Pombo M, Casanueva FF, Dieguez C. Effect of growth hormone $(\mathrm{GH})$-releasing hormone $(\mathrm{GHRH})$, atropine, pyridostigmine, or hypoglycemia on GHRP-6-induced GH secretion in man. J Clin Endocrinol Metab 1993; 76: 168-171.

16. Hataya Y, Akamizu T, Takaya K, Kanamoto N, Ariyasu H, Saijo M, et al. A low dose of ghrelin stimulates growth hormone $(\mathrm{GH})$ release synergistically with GH-releasing hormone in humans. J Clin Endocrinol Metab 2001; 86: 4552.

17. Popovic V, Damjanovic S, Micic D, Djurovic M, Dieguez C, Casanueva FF. Blocked growth hormone-releasing peptide (GHRP-6)induced $\mathrm{GH}$ secretion and absence of the synergic action of GHRP6 plus GH-releasing hormone in patients with hypothalamopituitary disconnection: evidence that GHRP-6 main action is exerted at the hypothalamic level. J Clin Endocrinol Metab 1995; 80: 942-947.

18. Popovic V, Miljic D, Micic D, Damjanovic S, Arvat E, Ghigo E, et al. Ghrelin main action on the regulation of growth hormone release is exerted at hypothalamic level. J Clin Endocrinol Metab 2003; 88: 3450-3453.

19. Tannenbaum GS, Bowers CY. Interactions of growth hormone secretagogues and growth hormone-releasing hormone/somatostatin. Endocrine 2001; 14: 21-27.

20. Pandya N, Mott-Friberg R, Bowers CY, Barkan AL, Jaffe CA. Growth hormone $(\mathrm{GH})$-releasing peptide-6 requires endogenous hypothalamic GH-releasing hormone for maximal GH stimulation. J Clin Endocrinol Metab 1998; 83: 1186-1189.

21. Dickson SL, Doutrelant-Viltart O, Leng G. GH-deficient dw/dw rats and lit/lit mice show increased Fos expression in the hypothalamic arcuate nucleus following systemic injection of $\mathrm{GH}$-releasing peptide-6. J Endocrinol 1995; 146: 519-526.

22. Maheshwari HG, Rahim A, Shalet SM, Baumann G. Selective lack of growth hormone $(\mathrm{GH})$ response to the $\mathrm{GH}$-releasing peptide hexarelin in patients with $\mathrm{GH}$-releasing hormone receptor deficiency. $J$ Clin Endocrinol Metab 1999; 84: 956-959.

23. Wren AM, Small CJ, Fribbens CV, Neary NM, Ward HL, Seal LJ, et al. The hypothalamic mechanisms of the hypophysiotropic action of 
ghrelin. Neuroendocrinology 2002; 76: 316-324.

24. Korbonits M, Little JA, Forsling ML, Tringali G, Costa A, Navarra P, et al. The effect of growth hormone secretagogues and neuropeptide $\mathrm{Y}$ on hypothalamic hormone release from acute rat hypothalamic explants. J Neuroendocrinol 1999; 11: 521-528.

25. Guillaume V, Magnan E, Cataldi M, Dutour A, Sauze N, Renard M, et al. Growth hormone (GH)-releasing hormone secretion is stimulated by a new $\mathrm{GH}$-releasing hexapeptide in sheep. Endocrinology 1994; 135: 1073-1076.

26. Goth MI, Lyons CE, Canny BJ, Thorner MO. Pituitary adenylate cyclase activating polypeptide, growth hormone (GH)-releasing peptide and $\mathrm{GH}$-releasing hormone stimulate $\mathrm{GH}$ release through distinct pituitary receptors. Endocrinology 1992; 130: 939-944.

27. Malagon MM, Luque RM, Ruiz-Guerrero E, Rodriguez-Pacheco F, Garcia-Navarro S, Casanueva FF, et al. Intracellular signaling mechanisms mediating ghrelin-stimulated growth hormone release in somatotropes. Endocrinology 2003; 144: 5372-5380.

28. Tolle V, Bassant MH, Zizzari P, Poindessous-Jazat F, Tomasetto C, Epelbaum J, et al. Ultradian rhythmicity of ghrelin secretion in relation with $\mathrm{GH}$, feeding behavior, and sleep-wake patterns in rats. Endocrinology 2002; 143: 1353-1361.

29. Okimura $Y$, Ukai K, Hosoda H, Murata M, Iguchi G, lida K, et al. The role of circulating ghrelin in growth hormone $(\mathrm{GH})$ secretion in freely moving male rats. Life Sci 2003; 72: 2517-2524.

30. Tannenbaum GS, Epelbaum J, Bowers CY. Interrelationship between the novel peptide ghrelin and somatostatin/growth hormonereleasing hormone in regulation of pulsatile growth hormone secretion. Endocrinology 2003; 144: 967-974.

31. Barkan AL, Dimaraki EV, Jessup SK, Symons KV, Ermolenko M, Jaffe CA. Ghrelin secretion in humans is sexually dimorphic, suppressed by somatostatin, and not affected by the ambient growth hormone levels. J Clin Endocrinol Metab 2003; 88: 2180-2184.

32. Halem HA, Taylor JE, Dong JZ, Shen Y, Datta R, Abizaid A, et al. Novel analogs of ghrelin: physiological and clinical implications. Eur J Endocrinol 2004; 151 (Suppl 1): S71-S75.

33. Zizzari P, Halem HA, Dong JZ, Taylor JE, Datta R, Culler MD, et al. BIM-28163, a full competitive antagonist of the GHS-1A receptor, attenuates spontaneous GH secretion without major alterations of food intake. Endocrine Society 87th Annual Meeting. 2005 June 4-7; San Diego.

34. Tannenbaum GS, Samia M, Chen Q, Bowers CY. Antagonism of the growth hormone secretagogue receptor unmasks a role for ghrelin in maintaining high $\mathrm{GH}$ pulse amplitude under physiological conditions. Endocrine Society 87th Annual Meeting. 2005 June 4-7; San Diego.

35. Pantel J, Cabrol S, Nivot S. Familial short stature associated with a mutation in the growth hormone secretagogue receptor (GHSR). Endocrine Society 86th Annual Meeting. 2004 June 16-19; New Orleans.

36. Koutkia P, Canavan B, Breu J, Johnson ML, Grinspoon SK. Nocturnal ghrelin pulsatility and response to growth hormone secretagogues in healthy men. Am J Physiol Endocrinol Metab 2004; 287 : E506-E512.

37. Kamegai J, Tamura H, Shimizu T, Ishii S, Tatsuguchi A, Sugihara $H$, et al. The role of pituitary ghrelin in growth hormone $(\mathrm{GH})$ secretion: $\mathrm{GH}$-releasing hormone-dependent regulation of pituitary ghrelin gene expression and peptide content. Endocrinology 2004; 145: 3731-3738.

38. Sun Y, Ahmed S, Smith RG. Deletion of ghrelin impairs neither growth nor appetite. Mol Cell Biol 2003; 23: 7973-7981.

39. Shuto $\mathrm{Y}$, Shibasaki T, Otagiri A, Kuriyama $\mathrm{H}$, Ohata $\mathrm{H}$, Tamura $\mathrm{H}$, et al. Hypothalamic growth hormone secretagogue receptor regulates growth hormone secretion, feeding, and adiposity. J Clin Invest 2002; 109: 1429-1436.

40. Sun $Y$, Wang $P$, Zheng $H$, Smith RG. Ghrelin stimulation of growth hormone release and appetite is mediated through the growth hormone secretagogue receptor. Proc Natl Acad Sci USA 2004; 101 : 4679-4684.

41. Peino R, Baldelli R, Rodriguez-Garcia J, Rodriguez-Segade $\mathrm{S}$, Kojima M, Kangawa K, et al. Ghrelin-induced growth hormone secretion in humans. Eur J Endocrinol 2000; 143: R11-R14.

42. Broglio F, Benso A, Castiglioni C, Gottero C, Prodam F, Destefanis $\mathrm{S}$, et al. The endocrine response to ghrelin as a function of gender in humans in young and elderly subjects. J Clin Endocrinol Metab 2003; 88: 1537-1542.

43. Cordido F, Penalva A, Dieguez C, Casanueva FF. Massive growth hormone $(\mathrm{GH})$ discharge in obese subjects after the combined administration of GH-releasing hormone and GHRP-6: evidence for a marked somatotroph secretory capability in obesity. $J$ Clin Endocrinol Metab 1993; 76: 819-823.

44. Tassone F, Broglio F, Destefanis S, Rovere S, Benso A, Gottero C, et al. Neuroendocrine and metabolic effects of acute ghrelin administration in human obesity. J Clin Endocrinol Metab 2003; 88: 54785483.

45. Maccario M, Arvat E, Procopio M, Gianotti L, Grottoli S, Imbimbo BP, et al. Metabolic modulation of the growth hormone-releasing activity of hexarelin in man. Metabolism 1995; 44: 134-138.

46. Di Vito L, Broglio F, Benso A, Gottero C, Prodam F, Papotti M, et al. The $\mathrm{GH}$-releasing effect of ghrelin, a natural $\mathrm{GH}$ secretagogue, is only blunted by the infusion of exogenous somatostatin in humans. Clin Endocrinol 2002; 56: 643-648.

47. Broglio F, Benso A, Gottero C, Prodam F, Grottoli S, Tassone F, et al. Effects of glucose, free fatty acids or arginine load on the $\mathrm{GH}$ releasing activity of ghrelin in humans. Clin Endocrinol 2002; 57: 265-271.

48. Maier C, Schaller G, Buranyi B, Nowotny P, Geyer G, Wolzt M, et al. The cholinergic system controls ghrelin release and ghrelin-induced growth hormone release in humans. J Clin Endocrinol Metab 2004; 89: 4729-4733.

49. Gertz BJ, Sciberras DG, Yogendran L, Christie K, Bador K, Krupa D, et al. L-692,429, a nonpeptide growth hormone (GH) secretagogue, reverses glucocorticoid suppression of $\mathrm{GH}$ secretion. J Clin Endocrinol Metab 1994; 79: 745-749.

50. Arvat E, Di Vito L, Gianotti L, Ramunni J, Boghen MF, Deghenghi R, et al. Mechanisms underlying the negative growth hormone $(\mathrm{GH})$ autofeedback on the $\mathrm{GH}$-releasing effect of hexarelin in man. $\mathrm{Me}$ tabolism 1997; 46: 83-88.

51. Leal-Cerro A, Pumar A, Garcia-Garcia E, Dieguez C, Casanueva FF. Inhibition of growth hormone release after the combined administration of GHRH and GHRP-6 in patients with Cushing's syndrome. Clin Endocrinol 1994; 41: 649-654.

52. Borges MH, DiNinno FB, Lengyel AM. Different effects of growth hormone releasing peptide (GHRP-6) and GH-releasing hormone on $\mathrm{GH}$ release in endogenous and exogenous hypercortisolism. Clin Endocrinol 1997; 46: 713-718.

53. Leal-Cerro A, Torres E, Soto A, Dios E, Deghenghi R, Arvat E, et al. Ghrelin is no longer able to stimulate growth hormone secretion in patients with Cushing's syndrome but instead induces exaggerated corticotropin and cortisol responses. Neuroendocrinology 2002; 76: 390-396.

54. Correa-Silva SR, Nascif SO, Silva MR, Senger MH, Miranda WL, Machado AF, et al. Decreased GH secretion and enhanced ACTH 
and cortisol release after ghrelin administration in Cushing's disease: comparison with GHRP-6. Proceedings of the 12th International Congress of Endocrinology. 2004 August 31-September 4; Lisbon.

55. Arvat E, Giordano R, Ramunni J, Arnaldi G, Colao A, Deghenghi R, et al. Adrenocorticotropin and cortisol hyperresponsiveness to hexarelin in patients with Cushing's disease bearing a pituitary microadenoma, but not in those with macroadenoma. $J$ Clin Endocrinol Metab 1998; 83: 4207-4211.

56. Pinto AC, Silva MR, Martins MR, Brunner E, Lengyel AM. Effects of short-term glucocorticoid deprivation on growth hormone $(\mathrm{GH})$ response to $\mathrm{GH}$-releasing peptide-6: studies in normal men and in patients with adrenal insufficiency. J Clin Endocrinol Metab 2000; 85: 1540-1544.

57. Ramos-Dias JC, Pimentel-Filho F, Reis AF, Lengyel AM. Different growth hormone $(\mathrm{GH})$ response to $\mathrm{GH}$-releasing peptide and $\mathrm{GH}$ releasing hormone in hyperthyroidism. J Clin Endocrinol Metab 1996; 81: 1343-1346.

58. Lengyel AMJ. From growth hormone-releasing peptides to ghrelin: discovery of new modulators of GH secretion. Arq Bras Endocrinol Metab 2006; 50: 17-24.

59. Villas-Boas Weffort RF, Ramos-Dias JC, Chipoch C, Lengyel AM. Growth hormone $(\mathrm{GH})$ response to $\mathrm{GH}$-releasing peptide- 6 in patients with insulin-dependent diabetes mellitus. Metabolism 1997; 46: 706-710.

60. Broglio F, Gianotti L, Destefanis S, Fassino S, Abbate DG, Mondelli $\mathrm{V}$, et al. The endocrine response to acute ghrelin administration is blunted in patients with anorexia nervosa, a ghrelin hypersecretory state. Clin Endocrinol 2004; 60: 592-599. 